\title{
Development of Software for Designing of Heat Exchanger
}

\author{
Harijan Anil Kumar ${ }^{1}$, Bagwe Nilesh ${ }^{2}$, Goud Vijay Kumar ${ }^{3}$, Karlag Vishal ${ }^{4}$ \\ 1, 2, 3, 4 B.E. Mechanical, Dilkap Research Institute of Engineering and Management Studies, Maharashtra, India
}

\begin{abstract}
Traditional design approaches are based on iterative procedures which assume a configuration and gradually change design parameters until a satisfactory solution is reached which meets the design specifications. However, such methods are time consuming. Hence software is built to make calculations easy. The diameter of tube, length of tube, diameter of shell is standardized and these are available only in certain sizes and shapes. They affect the overall heat transfer when the size and shape is changes. The main objective of this paper is to develop software and design a model on it. After designing a model for a given heat duty, study of effect of shell diameter, tube diameter, tube length and number of passes on two parameters first is tube side velocity and second is overall heat transfer are studied. The parameter which gives maximum heat transfer that has been selected for better optimization of shell and tube heat exchanger. For designing software a most resent version of Visual Basic called Visual Basic NET (VB.NET) is used because of its numerous advantages over the other software programs. The computer aided design software was equally used to test other problems on shell and tube heat exchanger. Using the software graphs and results carried out.
\end{abstract}

Keywords: shell and tube heat exchanger, Visual Basic NET, overall heat transfer, tube side velocity.

\section{Nomenclature}

$\mathrm{T}_{\mathrm{T} \text { in }}$ : Inlet temperature of tube side fluid.

$\mathrm{T}_{\mathrm{T} \text { out }}$ : Outlet temperature of tube side fluid.

$\mathrm{T}_{\mathrm{S} \text { in }}$ : Inlet temperature of shell side fluid.

$\mathrm{T}_{\mathrm{S} \text { out }}$ : Outlet temperature of shell side fluid.

$\mu_{\mathrm{s}}$ : Shell side fluid viscosity.

$\mu_{\mathrm{T}}$ :Tube side fluid viscosity.

$\mathrm{P}_{\mathrm{S}}$ : Shell side fluid density.

$\mathrm{P}_{\mathrm{T}}$ : Tube side fluid density.

$\mathrm{C}_{\mathrm{P}, \mathrm{s}}$ : Specific heat of shell side Fluid.

$\mathrm{C}_{\mathrm{P}, \mathrm{T}}$ : Specific heat of tube side Fluid.

$\mathrm{K}_{\mathrm{S}}$ : Thermal conductivity of shell side fluid.

$\mathrm{K}_{\mathrm{T}}$ : Thermal conductivity of tube side fluid.

$\mathrm{m}_{\mathrm{s}}$ : Shell side mass flow rate.

$\mathrm{m}_{\mathrm{T}}$ : Tube side mass flow rate.

Q : Heat duty or Heat transfer rate.

LMTD : Log Mean Temperature Difference.

$\mathrm{F}_{\mathrm{T}}$ : Correction factor.

$\mathrm{U}_{\text {ass.: }}$ : Assumed Overall heat transfer coefficient.

$\mathrm{U}_{\text {cal. }}$ : Calculated Overall heat transfer coefficient.

$\mathrm{A}_{\mathrm{HT}}$ : Heat transfer area.

$\mathrm{D}_{\mathrm{s}}$ : Inner diameter of Shell.

$\mathrm{d}_{0}$ : Outer diameter of Tube.

$\mathrm{d}_{\mathrm{i}}$ : Inner diameter of Tube.

$\mathrm{P}_{\mathrm{T}}$ : Tube pitch.

$B$ : Baffle Spacing.

$\mathrm{C}_{\mathrm{T}}$ : Tube Clearance.

$\mathrm{q}_{\mathrm{T}}$ : Tube side volume flow rate.

$\mathrm{D}_{\mathrm{H}}$ : Equivalent Diameter.

$\mathrm{R}_{\text {foul, shell }}$ : Fouling factor of shell side fluid.

$\mathrm{R}_{\text {foul, tube: }}$ Fouling factor of tube side fluid.

$\mathrm{f}_{\mathrm{s}}$ : Darcy friction factor for shell side fluid.

$\mathrm{f}_{\mathrm{T}}$ : Darcy friction factor for tube side fluid.

$\mathrm{N}_{\mathrm{p}}$ : Number of passes.

$\mathrm{N}_{\mathrm{B}}$ : Number of baffles.

g: Gravitational coefficient.

\section{Introduction}

Heat Exchangers are specialized devices that assist in the transfer of heat from one fluid to the other. In some cases, a solid wall may separate the fluids and prevent them from mixing. In other designs, the fluids may be in direct contact with each other. The most common type of heat exchangers used in the process, petroleum, chemical and HVAC industries intended for heating process fluids is Shell and Tube Heat Exchangers. Shell and tube heat exchangers are used when a process requires large amounts of fluids to be heated or cooled. Due to their design, they offer a large heat transfer area and provide high heat transfer efficiency. They consist of tubes and shells. The tubes act as the flow channels for one of the fluids in the heat exchanger, these exchangers are often parallel in order to provide a large surface area for the heat transfer.

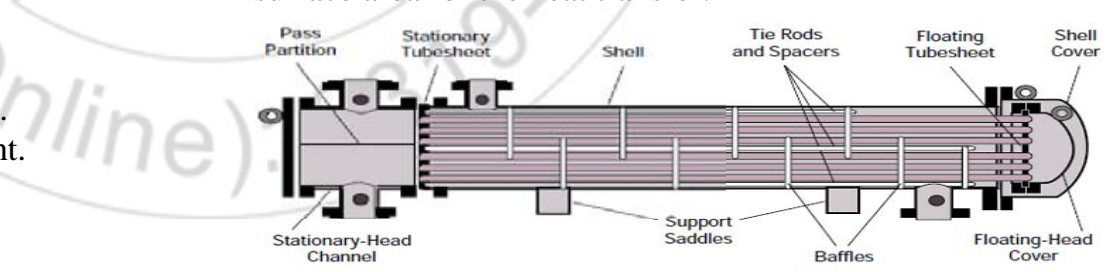

Figure 2.1: shell and tube heat exchanger

This exchanger, shown in Fig. 1.1, is generally built of a bundle of round tubes mounted in a cylindrical shell with the tube axis parallel to that of the shell. One fluid flows inside the tubes, the other flows across and along the tubes. The major components of this exchanger are tubes (or tube bundle), shell, frontend head, rear-end head, baffles, and tube-sheet.

\section{Literature Review}

While reviewing the works of professors it is seen that significant amount of works has been done in field of STHE. Some important works have been described in detail as under: 


\section{International Journal of Science and Research (IJSR) \\ ISSN (Online): 2319-7064}

Index Copernicus Value (2013): 6.14 | Impact Factor (2015): 6.391

A. Gopichand prof. A.V.N.L. Sharma [5] they carried out performance analysis of shell and tube type heat exchangers of water and oil type. The thermal analysis is done using MATLAB software which involves the determination of overall heat transfer coefficient.This paper shows how to do the thermal analysis by using theoretical formula and for this they have chosen a practical problem of counter flow shell and tube heat exchanger of water and oil type, by using the data that come from theoretical formulae they designed a model of shell and tube heat exchanger using Pro-E and did the thermal analysis by using FLOEFD software and comparing the result that obtained from FLOEFD software and theoretical formulae.

Durgesh Bhatt, Priyanka M Javhar[6] in this paper they use kern's method for designing a shell and tube heat exchanger. They took a heat exchanger problem an excel program was developed for further optimization of design. Using that program they show the effect of changing the parameters on overall heat transfer. By using modeling procedure assembly of shell and tube with water is done. By using ANSYS software, the thermal analysis of shell and tube heat exchanger is carried out. They conclude that copper tube is more effective as compare to brass tube.

Rajeev Mukherjee[7] first explained basic criteria for designing a heat exchanger also he gives classification of STHEs according to construction and according to service, data needed for thermal design which contain tube side design, shell side design, tube layout, baffling, shell side pressure drop and mean temperature difference. This paper gives overall idea to design optimal shell and tube heat exchanger.

Sampreeti Jena, Pandabapatro[8] In this paper the optimization was implemented by a multi objective genetic algorithm using MATLAB software. They had taken three design variables tube outside diameter, shell inside diameter, baffle spacing also two objective functions was simultaneously optimized to obtain a set of solution that yield the best value for the cost and length of heat exchanger.

Yusuf Ali Kara, OzbilenGuraras[9].They prepared a computer based design model for preliminary design of shell and tube heat exchangers with single phase fluid flow both on shell and tube side. They prepared program which determines all the parameters of shell, tube, optimum heat transfer surface area for given heat duty and allowable shell side pressure drop. They concluded that it is better to put the steam with lower mass flow rate on the shell side because of the baffle space.

Zahid H. Ayub [10] He prepared a chart method to calculate single- phase shell side heat transfer coefficient in a typical TEMA style single segmental shell and tube heat exchanger. A case study of rating water-to-water exchanger is shown to indicate the result from this method with the more established procedures and software's available in the market. He used well known HTRI software.

\section{Methodology}

$\mathrm{VB}$ is the third-generation event-driven programming language and integrated development environment (IDE) from Microsoft for its COM programming model. VB is also considered relatively easy to learn and use programming language, because of its graphical development features and BASIC heritage.

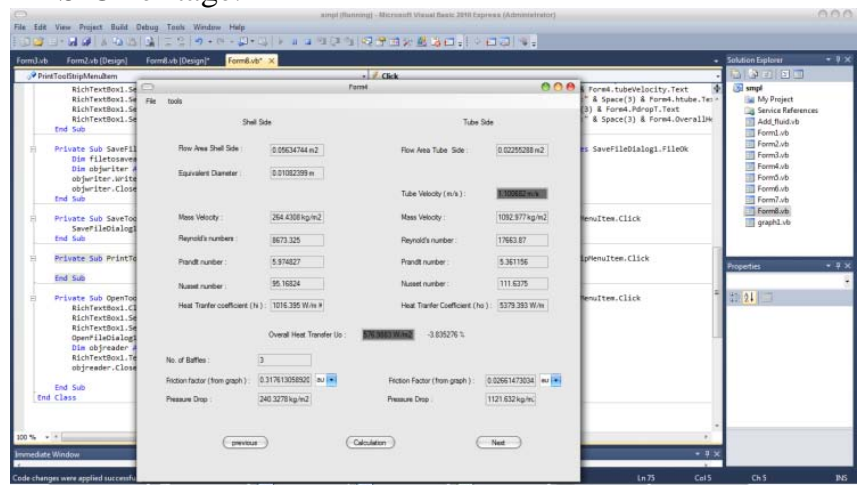

Figure 4.1: VB software,form 4

A programmer can put together an application using the components provided with Visual Basic itself. Programs written in Visual Basic can also use the Windows API, but doing so requires function declarations. The most widely used methods for designing shell and tube heat exchanger are Kern's method and Bell-Delaware method. For designing the software on VB we have used Kern's method because it provides conservative results. The designed software contain total 8 forms to give complete solution. The values for iteration are considered by taking a simple cooling application of industrial example:

The design of shell and tube heat exchanger involves the determination of overall heat transfer coefficients using kern (1965). The designed equations used for designing software are:

Heat duty:

$$
\mathrm{Q}=\mathrm{m}_{\mathrm{S}}\left(\mathrm{T}_{\mathrm{S} \text { in }}-\mathrm{T}_{\mathrm{S} \text { out }}\right)=\mathrm{m}_{\mathrm{T}}\left(\mathrm{T}_{\mathrm{T} \text { in }}-\mathrm{T}_{\mathrm{T} \text { out }}\right)
$$

Logarithmic mean temperature difference:

Correction factor:

$$
\mathrm{LMTD}=\frac{\Delta \mathrm{T}_{1}-\Delta \mathrm{T}_{2}}{\ln \frac{\Delta \mathrm{T}_{1}}{\Delta \mathrm{T}_{2}}}
$$

$$
\begin{gathered}
\mathrm{R}=\frac{\mathrm{T}_{\text {hot , in }}-\mathrm{T}_{\text {hot , out }}}{\mathrm{T}_{\text {cold , out }}-\mathrm{T}_{\text {cold ,in }}}, \mathrm{S}=\frac{\mathrm{T}_{\text {cold ,out }}-\mathrm{T}_{\text {cold ,in }}}{\mathrm{T}_{\text {hot ,in }}-\mathrm{T}_{\text {cold ,in }}} \\
F_{T}=\frac{\sqrt{\mathrm{R}^{2}+1} \ln \frac{1-\mathrm{S}}{1-\mathrm{RS}}}{(\mathrm{R}-1) \ln \frac{2-\mathrm{S}\left(\mathrm{R}+1-\sqrt{\mathrm{R}^{2}+1}\right)}{2-\mathrm{S}\left(\mathrm{R}+1+\sqrt{\mathrm{R}^{2}+1}\right)}}
\end{gathered}
$$

Heat transfer Area:

$$
\mathrm{A}_{\mathrm{HT}}=\frac{\mathrm{Q}}{\text { Uass }^{*} \mathrm{~F}_{\mathrm{T}} \text { LMTD }}
$$

Outer surface area of tube:

$$
\mathrm{a}_{\mathrm{ST}}=\pi \mathrm{d}_{\mathrm{o}} \mathrm{L}
$$

Number of tubes:

$$
\mathrm{N}_{\mathrm{T}}=\frac{\mathrm{A}_{\mathrm{HT}}}{\mathrm{a}_{\mathrm{ST}}}
$$

Equivalent diameter:

For triangular pitch: for square pitch:

$$
\mathrm{D}_{\mathrm{H}}=4 \frac{\left(\frac{\mathrm{P}_{\mathrm{T}}}{2}-86 \mathrm{P}_{\mathrm{T}}-\frac{\pi \mathrm{d}_{0}^{2}}{8}\right)}{\frac{\pi \mathrm{d}_{\mathrm{o}}}{2}} \mathrm{D}_{\mathrm{H}}=4 \frac{\left(\mathrm{P}_{\mathrm{T}}^{2}-\frac{\pi \mathrm{d}_{0}^{2}}{4}\right)}{\pi \mathrm{d}_{\mathrm{o}}}
$$




\section{International Journal of Science and Research (IJSR) \\ ISSN (Online): 2319-7064}

Index Copernicus Value (2013): 6.14 | Impact Factor (2015): 6.391

Flow area:

Final Report

Shell side: Tube side:

$$
\mathrm{a}_{\mathrm{S}}=\frac{\mathrm{C}_{\mathrm{T}} \mathrm{BD}_{\mathrm{S}}}{\mathrm{P}_{\mathrm{T}}} \mathrm{a}_{\mathrm{T}}=\mathrm{n} \frac{\pi}{4} \mathrm{~d}_{\mathrm{i}}^{2}
$$

Linear velocity inside tube:

$$
\mathrm{u}_{\mathrm{T}}=\frac{\mathrm{q}_{\mathrm{T}}}{\mathrm{a}_{\mathrm{T}}}
$$

Mass velocity:

Shell side: Tube side:

$$
\mathrm{G}_{\mathrm{S}}=\frac{\mathrm{m}_{\mathrm{S}}}{\mathrm{a}_{\mathrm{S}}} \mathrm{G}_{\mathrm{T}}=\frac{\mathrm{m}_{\mathrm{T}}}{\mathrm{a}_{\mathrm{T}}}
$$

Reynold's number:

Shell side: Tube side:

Prandtl's number:

$$
\operatorname{Re}_{\mathrm{S}}=\frac{\mathrm{D}_{\mathrm{H}} \mathrm{G}_{\mathrm{S}}}{\mathrm{S}} \operatorname{Re}_{\mathrm{T}}=\frac{\rho_{\mathrm{T}} \mathrm{u}_{\mathrm{T}} \mathrm{d}_{\mathrm{i}}}{\mathrm{T}}
$$

Shell side: Tube side:

Nusselt's number:

$$
\operatorname{Pr}_{\mathrm{S}}=\frac{\mathrm{C}_{\mathrm{p}, \mathrm{S}} \mathrm{S}}{\mathrm{K}_{\mathrm{S}}} \operatorname{Pr}_{\mathrm{T}}=\frac{\mathrm{C}_{\mathrm{p}, \mathrm{T}} \mathrm{T}}{\mathrm{K}_{\mathrm{T}}}
$$

Shell side:

$$
\mathrm{Nu}_{\mathrm{S}} \quad 36 \mathrm{Re}_{\mathrm{S}}{ }^{55} \mathrm{Pr}_{\mathrm{S}}{ }^{33}
$$

Tube side:

Laminar:

$$
\mathrm{Nu}_{\mathrm{T}} \quad 66+\frac{\left(\mathrm{d}_{\mathrm{i}} / \mathrm{L} \mathrm{Re}_{\mathrm{T}} \mathrm{Pr}_{\mathrm{T}}\right)}{\left(\mathrm{d}_{\mathrm{i}} / \mathrm{LRe}_{\mathrm{T}} \mathrm{Pr}_{\mathrm{T}}\right)^{2 / 3}}
$$

Turbulent:

$$
\mathrm{Nu}_{\mathrm{T}} \quad 27 \mathrm{Re}_{\mathrm{T}} \quad \operatorname{Pr}_{\mathrm{T}}
$$

Film Co-efficient:

Shell side: Tube side:

$$
\mathrm{h}=\mathrm{Nu}_{\mathrm{S}} \frac{\mathrm{K}_{\mathrm{S}}}{\mathrm{D}_{\mathrm{H}}} \mathrm{h}_{\mathrm{i}, \mathrm{T}}=\mathrm{Nu}_{\mathrm{T}} \frac{\mathrm{K}_{\mathrm{T}}}{\mathrm{D}_{\mathrm{i}}}
$$

Heat transfer coefficient:

$$
\mathrm{U}_{\text {cal... }}=\frac{1}{\left.\frac{1}{\mathrm{~h}}+\mathrm{R}_{\text {foul }, \text { shell }}+\frac{\mathrm{d}_{\mathrm{o}}}{\mathrm{d}_{\mathrm{i}}} \quad \text { foul , tube }+\frac{1}{\mathrm{~h}_{\mathrm{i}, \mathrm{T}}}\right)}
$$

Pressure drop:

Shell side: Tube side:

$$
\Delta P_{S}=\frac{\mathrm{f}_{\mathrm{S}} \mathrm{G}_{\mathrm{S}}^{2} \mathrm{D}_{\mathrm{S}}\left(\mathrm{N}_{\mathrm{B}}+1\right)}{2 \mathrm{~g} \rho_{\mathrm{S}} \mathrm{D}_{\mathrm{H}}} \Delta P_{T}=\frac{\mathrm{f}_{\mathrm{T}} \mathrm{G}_{\mathrm{T}}^{2} \mathrm{LN} \mathrm{N}_{\mathrm{p}}}{2 \mathrm{~g} \rho_{\mathrm{T}} \mathrm{d}_{\mathrm{i}}}
$$

\section{Results and Discussion}

$14.9 \mathrm{~kg} / \mathrm{s}$ of ethylene will cooled from $371.5 \mathrm{~K}$ to $338.5 \mathrm{~K}$ by using water as cold fluid which will be heated from $288.15 \mathrm{~K}$ to $298.15 \mathrm{~K}$ at inlet pressure of 3 bar at both shell and tube side nozzle. The complete thermal and mechanical design parameters derived for the considered industrial input. The report produced by the software is can be save or print directly. The report is shown below:
Inputs:

Shell side fluid : ethylene

Tube side fluid : water

Mass flow rate (shell) : $14.9 \mathrm{~kg} / \mathrm{s}$

Type of Flow : counter flow

Assumed overall heat transfer(Uass.) : $600 \mathrm{~W} / \mathrm{m} 2 \mathrm{~K}$

Design Inputs:

Shell inner Dia. : $482.6 \mathrm{~mm}$

Tube Outer Dia. : 15.875 mm

Tube pattern : triangular

Tube thickness : $1.473 \mathrm{~mm}$

Number of passes : 2

Design Outputs:

Shell Outer Dia. : 492.4375 mm

Shell Thickness : $4.91873 \mathrm{~mm}$

Tube Pitch : $19.685 \mathrm{~mm}$

Tube Inner Dia. : 12.929 mm

Number of tubes : 228

Number of Tubes per pass : 114

Baffle spacing : $60.325 \mathrm{~mm}$

Number of baffles : 3

Effective length : $2629.174 \mathrm{~mm}$

Mechanical Outputs:

Crown radius : $482.6 \mathrm{~mm}$

Knuckle radius : $28.956 \mathrm{~mm}$

Inside depth of head : $64.58686 \mathrm{~mm}$

Head thickness : $4.50687 \mathrm{~mm}$

Channel cover Thickness : $3.14899 \mathrm{~mm}$

Nozzle Diameter : $98 \mathrm{~mm}$

Nozzle Thickness : $3.007945 \mathrm{~mm}$

Tube-sheet thickness : $2.778037 \mathrm{~mm}$

Tube type : Fixed

Thermal Outputs:

Mass flow rate (tube) : $24.64978 \mathrm{~kg} / \mathrm{s}$

LMTD : $61.13056 \mathrm{~K}$

Shell side Flow area : $0.056348 \mathrm{~m} 2$

Shell side Reynold No. : 8673.325

Shell side Heat Transfer coefficient : $1016.39 \mathrm{~W} / \mathrm{m} \mathrm{K}$

Shell side pressure Drop (bars) : $240.3278 \mathrm{~kg} / \mathrm{m} 2$

Tubes side Flow area : $0.022553 \mathrm{~m} 2$

Tube side Reynolds No. : 17663.87

Tube Side Fluid velocity : $1.100682 \mathrm{~m} / \mathrm{s}$

Tube side Heat transfer coefficient : 5379.39 W/m K

Tube side pressure Drop(bar): $1121.632 \mathrm{~kg} / \mathrm{m} 2 \mathrm{Overall} \mathrm{Heat}$ Transfer Coefficient(Ucal): 576.98 W/m2 K

While calculating, it is observed that parameters such as tube length, tube diameter shell diameter and baffle spacing are affecting the overall heat transfer which has to be $30 \%$ less or more of the assumed overall heat transfer and tube side velocity which has to be more than $1 \mathrm{~m} / \mathrm{s}$. A total 4 case considered, in every case we will be varying each parameter and take five readings for each and observe the effect on overall heat transfer. 


\section{International Journal of Science and Research (IJSR) \\ ISSN (Online): 2319-7064 \\ Index Copernicus Value (2013): 6.14 | Impact Factor (2015): 6.391}

Case 1: Effect of tube length on $U$ and tube velocity

Table 5.1

\begin{tabular}{|c|c|c|c|c|c|}
\hline Tube length $(\mathrm{m})$ & 2.4 & 2.5 & 2.8 & 3.0 & 3.2 \\
\hline $\begin{array}{c}\text { Overall heat transfer } \\
(\mathrm{w} / \mathrm{m} 2 \mathrm{k})\end{array}$ & 574.34 & 576.983 & 583.5 & 587.48 & 590.38 \\
\hline Tube side velocity $(\mathrm{m} / \mathrm{s})$ & 1.0544 & 1.1006 & 1.231 & 1.3243 & 1.3958 \\
\hline
\end{tabular}

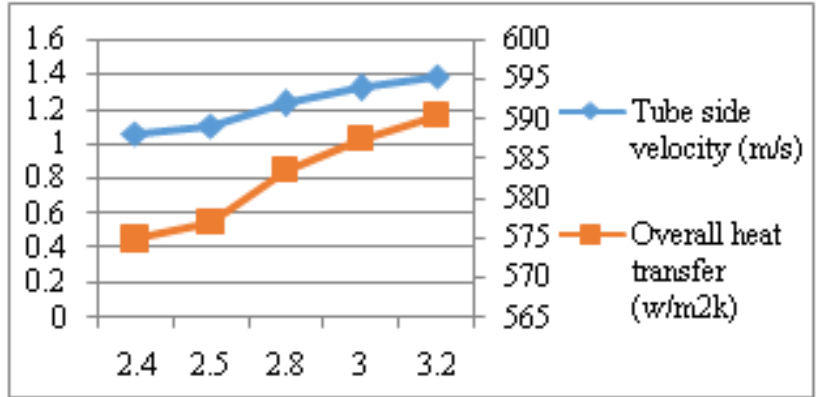

Figure 5.1: Tube length Vs U and Tube side velocity

As the tube length is increased the no. of tubes will start to decrease. This will lead to increase tube side Reynold's number. That will in turn increase overall Heat transfer coefficient (U). Following is the graph shows effect of tube length Vs overall heat transfer coefficient and tube velocity which is to be greater than $1 \mathrm{~m} / \mathrm{s}$.

Case 2: Effect of tube Diameter

Table 5.2

\begin{tabular}{|c|c|c|c|c|c|}
\hline Tube Diameter (inch) & .375 & .5 & .625 & .875 & 1 \\
\hline $\begin{array}{c}\text { Overall heat transfer } \\
\text { (w/m2k) }\end{array}$ & 572.7 & 584.24 & 576.98 & 530.95 & 500.38 \\
\hline Tube side velocity $(\mathrm{m} / \mathrm{s})$ & 1.834 & 1.371 & 1.101 & .780 & .662 \\
\hline
\end{tabular}

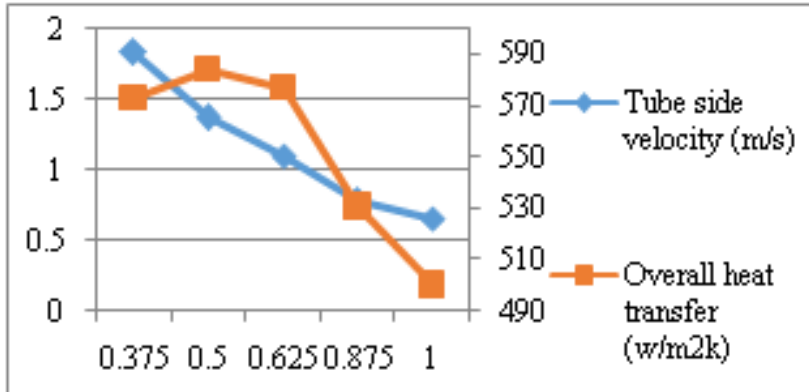

Figure 5.2: Tube diameter Vs U and Tube side velocity

As the tube diameter is increased it decreases tube side Reynolds's no. As well as it increases equivalent dia. Which leads to increase in shell side Reynold's number, because of which from .375 to .5 the overall heat transfer is increased at first and after that it goes on decreasing. Following graph shows effect of tube diameter Vs overall heat transfer coefficient.

Case 3: Effect of Shell diameter

Table 5.3

\begin{tabular}{|c|c|c|c|c|c|}
\hline Shell diameter (inch) & 17 & 18 & 19 & 20 & 21 \\
\hline $\begin{array}{c}\text { Overall heat transfer } \\
(\mathrm{w} / \mathrm{m} 2 \mathrm{k})\end{array}$ & 617.39 & 596.54 & 576.98 & 558.58 & 541.23 \\
\hline
\end{tabular}

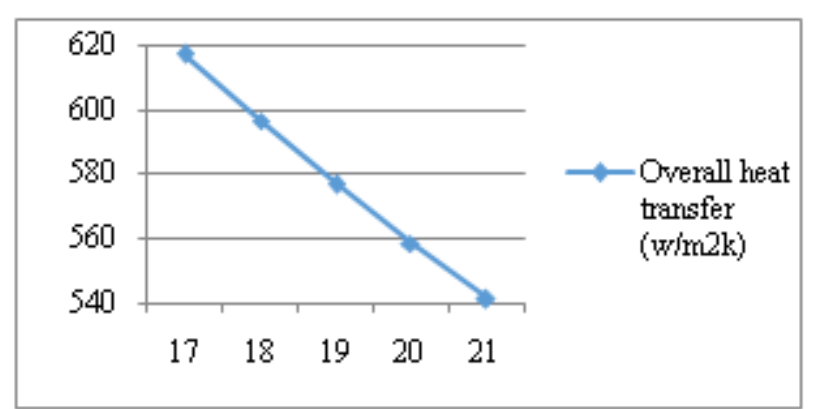

Figure 5.3: Shell diameter Vs U

As the shell diameter is increased the mass velocity decrease due to increase in shell side flow area. Which leads to decrease in shell side Reynold's number. That leads to decreasing overall heat transfer coefficient. Following graph shows effect of shell diameter Vs overall heat transfer.

Case 4: Effect of Baffle spacing

Table 5.4

\begin{tabular}{|l|l|l|l|l|l|}
\hline Baffle spacing (m) & .58 & .61 & .63 & .66 & .68 \\
\hline OHT (w/m2k) & 584.35 & 576.95 & 569.933 & 563.1 & 556.46 \\
\hline
\end{tabular}

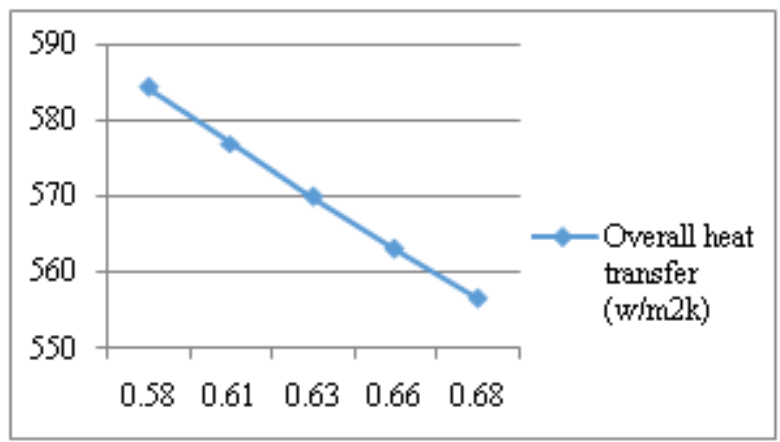

Figure 5.4: Shell diameter Vs U

As the baffle spacing is increased it reduces the number of baffles. This leads to decrease the Reynold's number. That leads to decrease the overall heat transfer coefficient. Following graph shows the effect of baffle spacing Vs overall heat transfer coefficient.

\section{Conclusion}

Results shows, changing the values of the parameters affects overall heat transfer coefficient. Therefore while designing, parameters are supposed to be choose wisely. This can only be achieved by shear experience and prediction or by varying each parameter and selecting an optimum solution. But the process of getting solution will be time more consuming. With the help of the software the iteration can be completed in seconds. As well as each solution can be saved and then compared to obtain anoptimum solution.

\section{Acknowledgement}

It is indeed a matter of great pleasure \& privilege to be able to present this research paper on "Development of Software for Designing of Heat Exchanger" under the valuable guidance of Prof. R. G. Mundhe\& Head of Department (Mechanical, DRIEMS) Prof. Sanjay Naikwade, We also 
convey our great thanks to our Esteemed PRINCIPAL Dr. Ajoy Kumar, who has been helping us directly or indirectly by providing us necessary amenities for working inside the college campus, which has helped us for this project.

\section{References}

[1] Indian Standard (IS: 4503-1967): Specification for Shell and Tube Type Heat Exchangers, BIS 2007, New Delhi.

[2] Standards of the Tubular Exchanger Manufacturers Association (TEMA), Inc. 18 ed., 1999, New York.

[3] Kuppan T. Heat Exchanger Design Handbook, Marcel Dekker, Inc. 2000, New York.

[4] D.Q. Kern, Process Heat transfer, McGraw-Hill, 1950, New York.

[5] A.Gopichand, A. V. N. L. Sharma, G. Vijay Kumar, A. Srividya, "Thermal Analysis of Shell and Tube Heat Exchanger Using MATLAB And FLOEFD Software",(2012) 2321-7380.

[6] Durgesh Bhatt, Priyanka M Javhar,“ Shell and Tube Heat Exchanger Performance Analysis",(2014) 23197064

[7] Mukherjee R., "Effectively Design shell and tube heat exchangers Chemical Engineering Progress",Feb.1998.

[8] Sampreeti Jena, PandabaPatro, Siddhartha ShankarBehera,"Multi-Objective Optimization of Design Parameters of a Shell \&Tube type Heat Exchanger using Genetic Algorithm",(2013) 2277-4106.

[9] Yusuf Ali Kara, OzbilenGuraras, "A computer program for designing of Shell and tube heat exchanger", AppliedThermal Engineering 24(2004) 1797-1805

[10]Zahid H. Ayub, "A new chart method for evaluating single-phase shell side heat transfer coefficient in a single segmental Shell and tube heat exchanger", Applied Thermal Engineering 25 (2005) 2412-2420. 